\title{
Missing Persons And Social Exclusion ${ }^{1}$
}

\author{
LAURA KiePal \\ Peter J. Carrington \\ MYrna DAWSON
}

Abstract. The concept of social exclusion is used to explore the relationship between people and groups who may be socially and economically disadvantaged and the phenomenon of going missing. Police data about missing persons are compared to census data to determine whether groups who experience family dissolution, labour market exclusion, and other forms of disadvantage and social exclusion are overrepresented among people reported missing compared to the general population. The analysis shows that disadvantaged youth, women, Aboriginal people, people who are not in the labour force, unemployed people, and homeless people are all overrepresented among people reported missing. People occupying the intersections of multiple high risk categories are at particularly high risk of being reported missing. Linking missing persons with the concept of social exclusion shows that social and economic disadvantage can lead directly and indirectly to peoples' disappearances.

Key words: missing persons, social exclusion, disadvantage, runaway youth, Aboriginal, risk factors

Résumé. Le concept d'exclusion sociale sert à explorer la relation entre les personnes et les groupes qui peuvent être défavorisés sur le plan social et économique et le phénomène de disparaître. Les données de la police au sujet des personnes disparues sont comparées aux données du recensement afin de déterminer si les groupes qui subissent un éclatement de la famille, une exclusion du marché du travail et autre forme de désavantage et d'exclusion sociale sont surreprésentés parmi les personnes portées disparues par rapport à la population générale. L'analyse démontre que les jeunes, les femmes, les Autochtones et les personnes qui ne font pas partie de la population active, les chômeurs et les sans-abri sont tous surreprésentés chez les personnes portées disparues. Les personnes qui se trouvent aux intersections de plusieurs catégories à risque élevé sont particuliè-

1. Acknowledgments: The authors gratefully acknowledge statistical advice from John Goyder and Rob Hiscott. The authors gratefully acknowledge the suggestions made by the anonymous referees and the editor, which resulted in a significantly improved paper. The research was supported by a Standard Research Grant from the Social Sciences and Humanities Research Council. Please direct correspondence to Laura Kiepal, Department of Sociology, University of Waterloo, Waterloo, Ontario N2L 3G1. E-mail: lvandong@uwaterloo.ca. 
rement à risque d'être portée disparue. Le lien entre les personnes disparues et le concept d'exclusion sociale démontre que le désavantage social et économique peut directement et indirectement mener à la disparition de quelqu'un.

Mots clés : personnes disparues; exclusion sociale; désavantage; Autochtone;

\section{INTRODUCTION}

$\sqrt{V} /$ hile there are no records for the total number of people who go 1 missing each year, police records from one Canadian city with a population of about 500,000 show that approximately 2,900 people were reported missing in 2006. Although most people are presumed to go missing voluntarily, in many cases disappearances arise as a response to circumstances over which people have limited control. For example, many people believe that youth who go missing are going through a rebellious stage when, in fact, many of them come from disadvantaged backgrounds and are escaping violence, abuse, and neglect (James et al. 2008; Dalley 2007). Among adults, financial crises, homelessness, mental illness, and domestic violence are linked to their disappearances (Association of Chief Police Officers 2005; Biehal et al. 2003). Yet, adults receive little attention from police and policy makers perhaps due to the common misperception that adults go missing voluntarily (Biehal et al. 2003). This misconception stems from the fact that little attention has been paid to systemic factors underlying adult disappearances.

By integrating insights from social exclusion with police data about missing persons, this research identifies excluded groups who face a high risk of being reported missing. Social exclusion examines structural processes that shut out particular groups and individuals from social relationships and economic activities to which other people in that society have access (Percy-Smith 2000; Burchardt et al. 1999; Peace 2001). Although the root causes are structural, social exclusion affects particular individuals and groups who are vulnerable to discrimination and segregation (Percy-Smith 2000; Silver 1994; Byrne 2005). With respect to missing persons, studies in Canada show that excluded groups such as disadvantaged youth, women escaping domestic violence, $\mathrm{Ab}$ original people, and visible minorities go missing in high numbers (Patterson 2005; Saskatchewan Association of Chiefs of Police 2007; Dalley 2007). International research confirms these findings and adds that a background of homelessness is common in missing persons (Biehal et al. 2003; Dedel 2006; James et al. 2008).

However, the current research about missing persons is inadequate for identifying which groups face a high risk of going missing. Re- 
search in Canada is mostly descriptive and samples are generally limited to sub-sets of missing persons such as youth and outstanding missing persons, meaning people who have not yet been found (Dalley 2007; Patterson 2005; Saskatchewan Association of Chiefs of Police 2007). There is little research in Canada about missing adults. Studies in other countries incorporate broader samples, but most are limited to describing these samples (Tarling and Burrows 2004; Newiss 1999; James et al. 2008; Biehal et al. 2003) or assessing who is likely to experience particular outcomes such as death (Newiss 2004) or to remain missing (Newiss 2005). These studies lack a comparison group with the general population and so are inadequate for identifying groups who are at risk of going missing. Moreover, prior research, particularly with runaway and homeless youth, shows that specific circumstances such as a history of abuse, family breakdown, and problems at school, are common in the background of people who go missing (James et al. 2008; Gaetz 2004). However, most studies examining the larger population of missing people are descriptive and are designed to improve and enhance the police response (Dalley 2007; Cohen et al. 2008). Few have incorporated sociological theory which is well-suited to explore and explain the issues that underlie peoples' disappearances.

To address these gaps in the literature, this study relies on the concept of social exclusion and compares missing persons data with data from the Statistics Canada 2006 Census and other population-based surveys to identify excluded groups who face a high risk of being reported missing. This research offers several major advantages over past research on missing persons. First, this is one of few studies in Canada that incorporates data about adults reported missing. Moreover, this research design includes comparisons with the general population to identify groups who are overrepresented among missing persons and, therefore, face a disproportionate risk of being reported missing. Finally, social exclusion draws attention to the systemic issues that may contribute to peoples' disappearances.

\section{Defining Missing Persons}

Going missing is a complex phenomenon and is conceptualized in various ways. This research relies on police data about missing persons, meaning someone must have noticed that a person is missing, perceived this disappearance as a problem, and filed a missing person report that is accepted by the police service as legitimate. In general, legal definitions employed by police services tend to place a high priority on abductions 
and other cases where the disappearance is not believed to be voluntary. Moreover, police data only include people who are reported as missing (Association of Chief Police Officers 2005); and yet, not everyone who goes missing is reported. As a result, legal definitions underestimate the complex motivations behind peoples' disappearances and the number of people who go missing.

One definition which offers an in-depth understanding of the problem, conceptualizes missing people along a continuum from forced disappearances to cases where people intend to end contact with family and friends (Biehal et al. 2003). Forced disappearances include abductions and violent crimes where the absence is unintentional on the part of the missing person. Intentional disappearances involve cases where people make a decision to disappear. However, this group may often feel forced to flee when confronted with problems with which they are unable to cope such as youth escaping violence or abuse at home or women fleeing domestic violence. In other words, even if it appears that people choose to go missing, their decision is often motivated by adverse events over which they have little control. In between these two extremes are disappearances that are unintentional but not forced such as elderly people who wander off, family members who drift out of contact over time, and homeless people who move between shelters and lose contact with family and friends (Biehal et al. 2003).

Formal identification as a missing person by police or another search agency is further complicated by dependence on a third party who defines someone as missing and the police service who receives the report (Payne 1995). These issues are captured in the following definition of going missing:

... a social situation in which a person is absent from their accustomed network of social and personal relationships to the extent that people within that network define the absence as interfering with the performance by that person of expected social responsibilities, leading to a situation in which members of the network feel obliged to search for the missing person and may institute official procedures to identify the person as missing. (Payne 1992, cited in Payne 1995:335)

This definition draws attention to a number of factors that affect who is likely to be reported missing. Someone must be aware of a person's absence, concerned about their well-being, and willing to institute official procedures to identify the person as missing (Payne 1995). Therefore, people who lack any connection with family, community, or a social agency such as social services are likely to go unnoticed and unreported if they go missing. Groups who are reticent about interacting with police 
are often unwilling to file a missing persons report, and are likely to be underrepresented in police data. A report by the Native Women's Association of Canada (NWAC) (2009), explains that Aboriginal people are often reticent about interacting with the police and this is one reason why missing Aboriginal people often go unreported. Also, certain people, such as youth, who face an especially high risk of encountering harm while missing may be reported missing more frequently compared to adults who are better able to access resources such as employment and shield themselves from harm if they go missing. Finally, people in a social network notice someone is missing and engage the police to trace, locate, and return this person. However, people who go missing to escape violence, abuse, and other perilous circumstances often do not consider themselves missing at all; for them, being located and returned is not a desirable outcome (Payne 1995). Research must take these underlying problems into account so that policies of prevention can provide people with alternatives to going missing rather than simply return people to the unhappy and unpleasant circumstances from which they are fleeing (Payne 1995). The concept of social exclusion draws attention to these underlying issues. Moreover, as emphasized in the above definitions, being reported missing and going missing are not equivalent phenomena and the causal factors leading to each may not overlap in every situation.

\section{Social Exclusion}

The concept of social exclusion refers to structural processes that prevent particular people and groups from participating in the economic, social, cultural, and political activities that other people in that society access thereby resulting in a poor quality of life (Percy-Smith 2000). This definition highlights four aspects of social exclusion: social exclusion is multidimensional, leads to poverty and other negative outcomes, is linked to structural processes that are outside peoples' control, and arises among marginalized groups and areas.

First, social exclusion is multidimensional, arising when people are shut out from a broad range of social and economic activities that allow people to achieve a socially acceptable standard of living (Room 1995; Percy-Smith 2000; Burchardt et al 1999; Byrne 2005; Peace 2001; Sen 2000). Access to social institutions such as family, healthcare, and education promote active participation in society and help to ensure an adequate standard of living. Access to welfare and social assistance are also important social institutions that mitigate the negative consequences of poverty and unemployment (Peace 2001; Percy-Smith 2000). People 
may lack access to the labour market or be excluded from permanent, full-time, positions and relegated instead to temporary, part-time, and generally poorly paid jobs. The labour market and other economic opportunities that provide valuable work skills, experience, along with networks and contacts are also vital to achieving a socially acceptable standard of living (Sen 2000). Isolation from social institutions such as the family and persistent lack of participation in the labour market are two important indicators of social exclusion.

Second, social exclusion leads to negative outcomes. Poverty is one important outcome which affects individuals and groups. Individuals experience low-skill levels, joblessness, family dissolution, fear of crime, substance abuse, mental illness, and poor health (Social Exclusion Unit 2000; Peace 2001). At the aggregate level, high crime rates, neighbourhood decay, and high unemployment rates are important indicators of social exclusion (Social Exclusion Unit 2000; Peace 2001). The impact of these outcomes is often reciprocal and dynamic in that an outcome of exclusion is often a cause of further social exclusion.

Third, social exclusion is related to structural processes over which people have limited control (Percy-Smith 2000). Persistent unemployment or precarious employment that is linked to the decline in manufacturing industries and increases in casual and part-time employment constitutes social exclusion (Percy-Smith 2000). As one British study points out, massive declines in the youth labour market precludes young people from making smooth transitions from education into full-time employment (Fergusson 2004). This decline coupled with major changes in postsecondary education and the benefit structure leaves many youth excluded and downloads the responsibility for inclusion onto the individual and the family (Fergusson 2004). Family dissolution is another process associated with social exclusion (Peace 2001). Although family separation is not always negative, the family can mitigate the negative consequences of unemployment and provides support for dependents and those who are unable to provide for themselves such as youth, elderly, and disabled people. Moreover, family dissolution is often set in motion by family violence, abandonment, divorce, or some other negative life event. The long-term psychosocial effects of these negative life events which can include low self esteem, depression, lack of integration in social networks, work relations, and conventional society are all associated with social exclusion (Peace 2001:25). Research in Canada shows that youth who experience family violence or other form of dysfunction in the home are more likely to have negative experiences at school, have fewer friends, and lower levels of participation in recreational activities — all of which are associated with social exclusion (Hanvey 2003). The 
point is that family dysfunction and separation can be a stressful event and people who experience these events often have fewer resources to rely on to cope with hardship compared to people with stable family backgrounds. Thus, unemployment and family dissolution are indicators of social exclusion.

Fourth, social exclusion has a group dimension. Particular groups face a disproportionate risk of exclusion, either because they differ in some way from the dominant population or because of their position within society. (Percy-Smith 2000:11). Group differences leading to exclusion encompass ethnicity, disability, drug abuse, alcoholism, homelessness, criminal involvement, and other stigmatizing lifestyles (PercySmith 2000; Peace 2001; Burnstein 2005). Single parents, disadvantaged youth, and the elderly are also vulnerable to exclusion (Charette and Meng 1994; Percy-Smith 2000). Finally, social exclusion has a spatial dimension and can affect entire areas if poverty, unemployment, crime, and other problems associated with social exclusion are heavily concentrated in particular communities and neighbourhoods (Peace 2001; Percy-Smith 2000). However, it is important to note that simply belonging to one of these groups or areas does not mean that a person is necessarily excluded (Percy-Smith 2000). For example, not every disabled person is excluded. Rather, if negative outcomes and low levels of participation are concentrated among particular groups or geographic areas, this constitutes social exclusion (Percy-Smith 2000).

Therefore, social exclusion is identified by lack of access to important activities and institutions such as the family and the labour market, negative outcomes, structural processes, and has a group and spatial component. The following section shows that social exclusion is a helpful framework for understanding groups who are at risk of going missing: those who are shut out from relationships with family and communities, come from disadvantaged backgrounds, experience unemployment, poverty, and other negative outcomes, reside in underprivileged communities, and are members of marginalized groups.

\section{Missing Persons and Social Exclusion}

The literature on missing persons in Canada and worldwide describes samples of missing people and identifies groups who go missing in high numbers (Dalley 2007; Patterson 2005; Saskatchewan Association of Chiefs of Police 2007; Newiss 1999; Tarling and Burrows 2004; Biehal et al. 2003; James et al. 2008). We review this literature in relation to the indicators of social exclusion identified above. 


\section{Youth}

The literature on missing persons in Canada, and worldwide, shows that youth go missing in high numbers (Dalley 2007; Newiss 1999; Tarling and Burrows 2004; James et al. 2008). Many youth who go missing are excluded through persistent poverty, homelessness, low levels of education, unemployment, and family dissolution brought about by violence, abuse, and neglect (Gaetz 2004). Moreover, youth who run away are more likely compared to other youth to be shut out from school, have problems with drugs and alcohol, and be in conflict with the law, further signs that they are disadvantaged (Social Exclusion Unit 2002). According to the Canadian Police Information Centre (CPIC), Canada's national database of missing persons, 60,461 youth were reported missing to police services in 2006 (Dalley 2007). CPIC classified 77\% of missing youth as runaways (Dalley 2007), defined as anyone under 18 years old who stays away from home or care without permission (Dalley 2007). Despite being classified as voluntarily missing, studies with youth show that runaways are often escaping abuse, parents' substance abuse, violence between caregivers, or some other type of conflict at home (Crespi and Sabatelli 1993; Hagan and McCarthy 1997; James et al. 2008; Public Health Agency of Canada 2006; Dedel 2006). Youth who flee their homes are often reported missing by parents or other family members.

The relationship between family dissolution and youth disappearances is a sign that social exclusion plays a role in youth disappearances. Youth are generally reliant on their families for support, subsistence, housing, and income (Phipps and Burton 1995). Youth whose families are excluded will also lack access to vital resources or opportunities (Hanvey 2003). In fact, the family takes on increasing responsibility for youth given the decline in the youth labour market and other structural changes affecting youth transitions into permanent, secure employment (Fergusson 2004). Therefore, family dissolution exposes youth to serious strain and deprives them of resources needed to cope with problems. In a U.K. study runaway youth claimed that family problems were the leading reason behind their disappearances (Social Exclusion Unit 2002). On the other hand, this same study found that positive relationships with family and friends reduced the likelihood of youth running away (Social Exclusion Unit 2002). Among youth who are dependent on their families, family conflict and dissolution leads them often to end up in care facilities such as group homes and foster homes. Youth may end up in care if their families are unable to provide for them, if they have experienced violence or witnessed violence between caregivers, or if they are abandoned by caregivers (Public Health Agency of Canada 
2006). A high number of youth go missing from care (James et al. 2008; Dalley 2007). This is supported by a Canadian study which found that, of the 60,461 youth reported missing in 2006, 14\% went missing from child care and $20 \%$ from foster care (Dalley 2007). The risks to youth in care are discussed later on.

Youth who run away from home or care are often exposed to harm. Compared to youth who live at home, runaway and homeless youth are more likely to experience physical victimization, sexual exploitation, drug and substance abuse problems (Gaetz 2004; Public Health Agency of Canada 2006; Payne 1995; Hagan and McCarthy 1997; Social Exclusion Unit 2002), and become involved in risky and illegal activities (Gaetz 2004; Payne 1995). A U.K. study of 13,000 runaway youth found that one quarter had slept on the streets while missing and many survived through illegal and dangerous means such as stealing, begging, or prostitution (Social Exclusion Unit 2002). Therefore, youth who go missing from home or care are often marginalized and running away exposes them to harm, further entrenching their marginal status (Gaetz 2004).

\section{Aboriginal People}

Aboriginal people are another excluded group who go missing in high numbers in Canada. Police data from Saskatchewan reveal that Aboriginal people were overrepresented among outstanding missing persons compared to the total population of Aboriginal people in Saskatchewan (Saskatchewan Association of Chiefs of Police 2007). Moreover, the Native Women's Association of Canada (NWAC) indicates that 520 Aboriginal women have gone missing over the past few decades. In many cases, these women have been murdered or remain missing (Native Women's Association of Canada 2009).

Aboriginal people experience social exclusion in many areas of their lives, including poverty, spatial segregation on Aboriginal reserves, labour market exclusion, and isolation from family and communities (Amnesty International 2004). In 2005, 22\% of Aboriginal people in Canada reported incomes below the Low Income Cut-off (LICO) compared to about $11 \%$ of the general population (Noël and Larocque 2009). Moreover, spatial segregation occurs on Aboriginal reserves which are characterized by high levels of poverty, persistent unemployment, crime, mental illness, suicide, and lack of affordable housing and healthcare (Amnesty International 2004; Noël and Larocque 2009). In 1996 the unemployment rate for Aboriginal people on reserves was $29 \%$ compared to $10 \%$ for non-Aboriginals (Canadian Centre for Justice Statistics 2001b). Aboriginal people flee from their homes to escape poverty, unemployment, and other problems commonly experienced on reserves, 
seeking greater opportunities in city centres, and can be reported missing by friends and family left behind (Amnesty International 2004). Aboriginal people in city centres continue to experience disproportionately high levels of poverty, homelessness, and other types of disadvantage associated with social exclusion. A 1998 national survey in Canada found that 125,000 Aboriginal people living off reserves had incomes below the Low Income Cut-off (LICO) (Burnstein 2005). This represents approximately $18 \%$ of all Aboriginal people living off reserves (Statistics Canada 2003). Aboriginal people living off reserves also experience social isolation from family and loneliness, particularly if they fled reserves to escape adverse conditions such as violence and abuse at home. The combination of poverty and social isolation puts Aboriginal people at risk of homelessness and other dangerous circumstances that are linked with going missing (Amnesty International 2004). Homelessness in relation to going missing is discussed below.

\section{Homelessness}

Homeless people are an excluded group who go missing in high numbers. They often lack ties to family, experience barriers to employment, and other forms of social exclusion prior to becoming homeless, and homelessness often exacerbates these conditions (Lee and Schreck 2005; Richter and Chaw-Kant 2008; Lee and Price-Spratlen 2004; Gaetz 2004; Gaetz and O'Grady 2002). Social and economic exclusion experienced by homeless people is described as disaffiliation within the literature on homelessness. Disaffiliation refers to limited connections with social and economic resources such as family, friends, and employment opportunities (Lee and Schreck 2005). One outcome of disaffiliation is chronic residential instability, leading in part to the high number of homeless people who are reported missing (Lee and Schreck 2005:1060). People without permanent homes often move from shelter to shelter. If people leave a shelter without notice, shelter staff are obligated to file a missing persons report even if the missing person is an adult. Homeless people who move about frequently may also be reported missing by someone in their social network who notices their absence and grows concerned about their whereabouts or well being.

\section{Domestic Violence}

Domestic violence leads to women's and children's disappearances (Patterson 2005; Association of Chief Police Officers 2005; James et al. 2008); victims of domestic violence often experience social and economic exclusion. A study of outstanding missing persons in British Col- 
umbia found that many missing women experienced domestic violence (Patterson 2005). The link between domestic violence and missing persons is confirmed by studies in the U.K. and Australia (Association of Chief Police Officers 2005; James et al. 2008). Women who flee their homes to escape violence are often reported missing by family members or friends who are concerned about their well being or by their spouse or partner.

Women's experiences of domestic violence are associated with social and economic exclusion which in some cases lead to disappearances. Research on partner violence notes that abused women often experience social and economic disadvantage (Public Health Agency of Canada 2008). Poverty and disadvantage make it difficult to access support services and resources to cope with violence and escape abuse (Public Health Agency of Canada 2008). Compared to nonabused women, abused women are less likely to have access to social support networks such as family and friends (Kantor and Jasinski 1998). Social isolation and loneliness means they have few resources to rely on to escape abuse. Finally, many abused women, especially those who are economically and socially disadvantaged are financially dependent on their partners and men use economic abuse to control them. Economic abuse includes preventing women from working, going to school, and controlling the family finances (Gondolf 1988). As a result, women who flee violent relationships are often confronted with poverty, homelessness, and other problems that are associated with social exclusion (Novac 2006) and going missing.

\section{Summary}

Linking missing persons research with the concept of social exclusion shows that excluded groups are reported missing in high numbers and demonstrates that social exclusion is related directly and indirectly to peoples' disappearances. Even disappearances that appear voluntary may be a response to circumstances such as abuse, family breakdown, and violence. Unlike past research, this study of missing persons introduces a comparison with the general population to identify groups who are overrepresented among missing persons. Further comparisons explore which excluded groups face a high risk of going missing. Group differences associated with social exclusion, such as gender, ethnicity, and labour market exclusion which have not been adequately assessed in Canadian research are explored. 


\section{Data ANd Methods}

The data for this research consist of a systematic ${ }^{2}$ sample derived from 2,896 missing persons reports made to one Canadian police service between January and December 2006. The researcher read one-quarter of all missing persons occurrence reports logged by a police service in 2006 in one Canadian city. ${ }^{3}$ Information about the demographic characteristics, where they were reported missing from, labour force status, and other information was collected from a total of 724 missing persons occurrence reports. ${ }^{4}$ These data are compared with census data from the same city and geographic area to identify overrepresented groups among missing persons.

Police data and census data are collected for different purposes, using different strategies and, therefore, the two data sets are not always directly comparable. Statistics Canada uses more categories than the police service to code ethnicity, and the census does not include homeless people and people living in institutions. One of the goals of this research is to explore the relationship between homelessness, youth residing in care facilities, and going missing. Therefore, statistics about shelter use and homelessness in the general population in this city were obtained from a report by the Social Planning and Research Council (2007) in this city. Data about the number of youth in Ontario who relied on group homes and foster homes were obtained from a study by the Ontario Association of Children's Aid Societies (2006).

The data for this research were collected by the primary researcher on behalf of a police service for the purpose of conducting an internal review of the police response to missing persons' cases. To complete the review, hard copies of missing persons occurrence reports were obtained and read. These reports include details about the missing people and the cases. Information about demographic characteristics such as age, gender, and ethnicity, the nature and circumstances surrounding the disappearances, and other details including the police response to the cases were coded in a spreadsheet in SPSS. Following the internal review, the police service granted the primary researcher permission to use these data for subsequent research initiatives.

2. The first missing persons report was selected using a table of random numbers. Following that, every fourth case was selected until the records were exhausted, resulting in the sample of 724 missing persons reports.

3. Reports are logged if a concerned family member, friend, social service worker, or other individual contacts the police either via telephone or in person. However the researchers have no information about whether all cases are logged and, if not, whether cases not logged differ in some important way from cases that are accepted.

4. As every fourth case was selected, these data represent incidents not individuals. It is probable that some individuals are included more than once within these data. 
Ethics approval for this particular research project was obtained from the university Review Ethics Board (REB) on several conditions. The first condition was that the name of the city and the police service remain confidential. Anonymity for the missing persons was an additional requirement for ethics approval, meaning that the names, addresses, and other personal identifiers of the missing people were removed from these data.

\section{RESULTS}

The following analyses compare the characteristics of missing people with data from the general population to identify excluded groups who were overrepresented among people reported missing in this city in 2006. As discussed above, past research on missing persons has identified youth, Aboriginal people, homeless people, youth in care facilities, and women escaping domestic violence as groups who go missing in high numbers. Visible minorities, women, unemployed people, and people who are not in the labour force are also vulnerable to social exclusion. It is hypothesized that each of the abovementioned groups will be overrepresented among missing persons.

\section{Missing Persons}

As a starting point, we report baseline statistics on the prevalence of persons reported missing in this city. In 2006, this police service with a population of approximately 500,000 people filed 2,896 missing persons reports. This is $0.57 \%$ of the people in this city, or a rate of 5.7 per 1,000 people. It is important to note that these data represent only people who were reported missing. Although the extent of underreporting of missing persons in this city or in Canada is not known, the statistics reported in this article are probably an underestimate of the number of missing persons.

\section{Duration of Disappearances}

The duration of people's disappearances varied greatly from one or two days to people who remain missing. In this sample, approximately $80 \%$ of people were found or returned on their own within 2 days of being reported missing, $20 \%$ of people were missing for 3 days or longer, and just over $10 \%$ were missing for 7 days or longer. There is some evidence that the duration of peoples' disappearances affects the likelihood that they will encounter harm (Newiss 2005). However, any disappearance, even if it is short term, may result in harm to the person who is missing, place stress and strain on family members and friends, and consume po- 
lice resources (Biehal et al. 2003). Most importantly, as this research attempts to show by linking missing persons with the concept of social exclusion, going missing for any length of time is often a sign of underlying problems and leads to problems later in life. A U.K. report found that adults who run away as youth are more likely, compared to those who never ran, to use drugs, have prison records, and experience homelessness (Social Exclusion Unit 2002). Focusing on groups who are at risk of going missing will also help to prevent other social problems.

\section{Youth}

Table 1 compares the age distributions of persons reported missing and the general population of the city. Young people 19 years of age and under accounted for $73 \%$ of all missing people in the sample, compared to $25 \%$ of the general population. The high proportion of youth among people reported missing is accounted for by two groups - 10-14 year olds and 15-19 year olds. Both groups faced a disproportionate risk of being reported missing. About $25 \%$ of the missing persons sample was $10-14$ years old compared to $7 \%$ of the general population. Slightly less than $50 \%$ of the missing persons sample were 15-19 year olds compared with only $7 \%$ of the general population. Every other age group was underrepresented among the sample. The group of 10-14 year olds were 5.3 times as likely as 20-24 year olds to be reported missing and 15-19 year olds were 9.8 times as likely — by far the highest risk of any age group.

\section{Table 1. Missing Persons and the General Population, by Age Group}

$\begin{array}{lcccc}\text { Age Group } & \begin{array}{c}\text { Percent of } \\ \text { Missing Persons } \\ \text { (25\% sample) }\end{array} & \begin{array}{c}\text { Percent of } \\ \text { General } \\ \text { Population }\end{array} & \begin{array}{c}\text { Missing Persons as a } \\ \text { Percent of the General } \\ \text { Population }\end{array} & \begin{array}{c}\text { Relative Risk } \\ \text { (versus 20-24 } \\ \text { year olds) }\end{array} \\ 0 \text { to } 4 & 0.8 & 5.3 & 0.1 & 0.3 \\ 5 \text { to } 9 & 1.0 & 5.8 & 0.1 & 0.3 \\ 10 \text { to } 14 & 24.7 & 6.6 & 2.1 & 5.3 \\ 15 \text { to } 19 & 46.7 & 6.9 & 3.9 & 9.8 \\ 20 \text { to } 24 & 5.3 & 6.8 & 0.4 & - \\ 25 \text { to } 29 & 2.6 & 6.0 & 0.3 & 0.8 \\ 30 \text { to } 34 & 2.1 & 6.1 & 0.2 & 0.5 \\ 35 \text { to } 39 & 1.8 & 6.9 & 0.2 & 0.5 \\ 40 \text { to } 44 & 4.6 & 8.2 & 0.3 & 0.8 \\ 45 \text { to } 49 & 2.8 & 8.1 & 0.2 & 0.5 \\ 50 \text { to } 54 & 1.7 & 7.2 & 0.1 & 0.3 \\ 55 \text { to } 59 & 2.1 & 6.3 & 0.2 & 0.5 \\ 60+ & 4.0 & 19.7 & 0.1 & - \\ \text { Total } \% & 100.0 & 100.0 & 0.6 & - \\ \text { Total } & 724 & 504,560 & & \\ X^{2}=2292.55, d f=12, p<0.001 & & \end{array}$




\section{Gender}

Table 2 shows that females faced a somewhat higher risk of being reported missing: the relative risk for females compared to males was 1.3. No statistics are currently available on the gender of all missing persons in Canada; however, a study in Australia based on national police data found that in 2005-2006, men and women were reported missing in about equal numbers (James et al. 2008).

\section{Table 2. Missing Persons and the General Population, by Gender}

$\begin{array}{lcccc}\text { Gender } & \begin{array}{c}\text { Percent of } \\ \text { Missing Persons } \\ \text { (25\% sample) }\end{array} & \begin{array}{c}\text { Percent of } \\ \text { General } \\ \text { Population }\end{array} & \begin{array}{c}\text { Missing Persons as a } \\ \text { Percent of the General } \\ \text { Population }\end{array} & \begin{array}{c}\text { Relative Risk } \\ \text { (versus the } \\ \text { other Gender) }\end{array} \\ \text { Female } & 58.0 & 51.0 & 0.7 & 1.3 \\ \text { Male } & 42.0 & 49.0 & 0.5 & 0.8 \\ \text { Total \% } & 100.0 & 100.0 & 0.6 & - \\ \text { Unknown } & 1 & 697 & \\ \text { Total } & 724 & 504,560 & \\ X^{2}=12.791, d f=1, p<0.001 & \end{array}$

\section{Aboriginal Identity}

Table 3 shows that Aboriginal people were overrepresented among this sample of missing persons: they accounted for $4 \%$ of the sample and only $1.6 \%$ of the general population of this city for a relative risk of 2.7 . No statistics are available on the Aboriginal status of all missing persons in Canada. In two Canadian provinces, however, studies showed that a relatively high number of outstanding missing persons were Aboriginal (Saskatchewan Association of Chiefs of Police 2007; Patterson 2005).

\section{Table 3. Missing Persons and the General Population, by Aboriginal Identity}

\begin{tabular}{lcccc}
$\begin{array}{c}\text { Aboriginal } \\
\text { Identity }\end{array}$ & $\begin{array}{c}\text { Percent of } \\
\text { Missing Persons } \\
\text { (25\% sample) }\end{array}$ & $\begin{array}{c}\text { Percent of } \\
\text { General }\end{array}$ & $\begin{array}{c}\text { Missing Persons as a } \\
\text { Percent of the General } \\
\text { Populion }\end{array}$ & $\begin{array}{c}\text { Relative Risk } \\
\text { (versus the other } \\
\text { Identity) }\end{array}$ \\
Aboriginal & 4.0 & 1.6 & 1.5 & 2.7 \\
Not Aboriginal & 96.0 & 98.4 & 0.6 & 0.4 \\
Total \% & 100.0 & 100.0 & 0.6 & - \\
Unknown & 5 & & & \\
Total & 724 & 504,560 & \\
$X^{2}=26.949, d f=1, p<0.001$ & \\
Source: Statistics for the general population were obtained from Statistics Canada, 2006 census, at \\
\multicolumn{2}{l}{ http://www12.statscan.ca/census-recensement/2006/dp-pd/prof/92-591/index.cfm?Lang=E. Ac- } \\
cess date: 12 December 2010.
\end{tabular}

\section{Ethnicity}

The ethnicities of missing persons and the general population of the city are compared in Table 4. Overall, visible minorities were not overrepresented among persons reported missing: they accounted for about $15 \%$ of 
reported missing compared to employed persons aged $15+$ years. Unemployed persons accounted for $23 \%$ of this sample compared to $4 \%$ of the general population. The relative risk of being reported missing for unemployed persons $15+$ years compared to employed persons $15+$ years was 26.0. Studies in Canada have not explored the labour force status of missing persons. However, in the U.K., mailed questionnaires completed by 65 adults reported missing after their return, showed that just over one-third were unemployed immediately prior to going missing (Biehal et al. 2003).

Table 5. Labour Force Status of Missing Persons and the General Population

$\begin{array}{lcccc}\begin{array}{l}\text { Labour } \\ \text { Force Status }\end{array} & \begin{array}{c}\text { Mercent of } \\ \text { Known Labour Force } \\ \text { Status (25\% sample) }\end{array} & \begin{array}{c}\text { Percent of } \\ \text { Peneral }\end{array} & \begin{array}{c}\text { Missing Persons } \\ \text { as a Percent of the } \\ \text { General Population }\end{array} & \begin{array}{c}\text { Relative Risk } \\ \text { (versus } \\ \text { Employed } \\ \text { Persons) }\end{array} \\ \text { Employed } & 7.8 & 60.4 & 0.1 & - \\ \text { Unemployed } & 22.5 & 4.2 & 2.6 & 26.0 \\ \text { Not in } & 69.7 & 35.3 & 1.0 & 10.0 \\ \text { labour force } & 100.0 & 100.0 & 0.5 & - \\ \text { Total percent } & 215 & & & \\ \text { Unknown } & 294 & 407,590 & \\ \text { Total } & \\ X^{2}=461.687, d f=2, p<0.001 & \\ \text { Source: Statistics for the general population were obtained from Statistics Canada, 2006 census, at } \\ \quad \text { http://www12.statscan.ca/census-recensement/2006/dp-pd/prof/92-591/index.cfm?Lang=E. Ac- } \\ \text { cess date: } 12 \text { December 2010. }\end{array}$

\section{Shelter Use and Homelessness}

Table 6 shows that people who relied on shelters ${ }^{7}$ were overrepresented compared to the general population in this city. Specifically $16 \%$ of the missing persons sample was reported missing from a shelter whereas only $1.1 \%$ of the general population relied on a shelter. Thus, shelter users were more than 17 times as likely to be reported missing as non shelter users. The relationship between going missing and homelessness is also reported by a U.K. study (Biehal et al. 2003).

\section{Table 6. Shelter Use among Missing Persons and the General Population}

$\begin{array}{lcccc}\begin{array}{l}\text { Where Missing } \\ \text { From }\end{array} & \begin{array}{c}\text { Percent of } \\ \text { Missing Persons } \\ \text { (25\% sample) }\end{array} & \begin{array}{c}\text { Percent of } \\ \text { General } \\ \text { Population }\end{array} & \begin{array}{c}\text { Missing Persons as a the General } \\ \text { Percentation }\end{array} & \begin{array}{c}\text { Relative Risk } \\ \text { (versus Other) }\end{array} \\ \text { Shelter } & 16.3 & 1.1 & 8.6 & 17.2 \\ \text { Other } & 83.6 & 98.9 & 0.5 & - \\ \text { Total Percent } & 100.0 & 100.0 & 0.6 & - \\ \text { Unknown } & 4 & & & \\ \text { Total number } & 724 & 504,560 & \\ X^{2}=1499.747, d f=1, p<0.001 \\ \text { Source: Statistics about shelter use in the general population were obtained from the Social Planning } \\ \text { and Research Council (SPRC) (2007). }\end{array}$

7. Shelters include homeless shelters and Violence Against Women shelters. 
Table 7 shows that, among shelter users, females were much more likely than males to be reported missing. Specifically, $15 \%$ of female shelter users were reported missing compared to $3 \%$ of males, meaning that female shelter users were almost five times as likely to be reported missing compared to males. Moreover, among persons reported missing from a shelter, $80 \%$ were female and $20 \%$ male. By comparison, females accounted for only about $44 \%$ of all shelter users and $56 \%$ were male (Social Planning and Research Council 2007). A closer look at these data shows that $88 \%$ of women reported missing from a shelter were in a Violence Against Women (VAW) shelter. According to a Canadian study, approximately $75 \%$ of women who rely on VAW shelters are escaping domestic violence (Sauvé and Burns 2009). The high number of women in this sample who were reported missing from a VAW shelter highlights the role that domestic violence plays in women's disappearances. This finding about the relationship between domestic violence and going missing is supported by research in Canada (Gaetz 2004) and worldwide (Association of Chief Police Officers 2005; James et al. 2008). It is important to note that shelter staff are typically obligated to file a missing persons report if women do not return to shelters by a designated time. This might explain, in part, the high number of women reported missing from shelters.

\section{Table 7. The Gender Distribution of Shelter Users in the Missing Persons} Sample and of all Shelter Users

$\begin{array}{lcccc}\text { Gender } & \begin{array}{c}\text { Percent of Missing } \\ \text { Shelter Users }(25 \% \\ \text { sample) }\end{array} & \begin{array}{c}\text { Percent of all } \\ \text { Shelter Users }\end{array} & \begin{array}{c}\text { Missing Shelter } \\ \text { Users as a Percent } \\ \text { of all Shelter Users }\end{array} & \begin{array}{c}\text { Relative Risk } \\ \text { (versus the }\end{array} \\ \text { Female } & 79.7 & 44.0 & 14.8 & 4.8 \\ \text { Male } & 20.3 & 56.0 & 3.1 & 0.2 \\ \text { Total \% } & 100.0 & 100.0 & 8.6 & \\ \text { Unknown } & 0 & 5,594 & \\ \text { Total } & 118 & & \\ X^{2}=55.908, d f=1, p<0.001 & \\ \text { Source: Statistics about shelter use in the general population were obtained from the Social Planning } \\ \text { and Research Council (SPRC) (2007). }\end{array}$

\section{Group/Foster homes}

Table 8 shows that youth in care were greatly overrepresented among people reported missing and faced an extremely disproportionate risk of being reported missing compared to all youth. Of all youth reported missing, 57\% were in care; whereas in the general population less than $1 \%$ of all youth were in care (Ontario Association of Children's Aid Services 2006). Thus, youth in care were more than 200 times as likely to be reported missing as youth not in care. A nation-wide study in Canada found that in $2006,34 \%$ of all missing youth had been in foster care 
or child care (Dalley 2007). International research with runaway youth confirms these findings (Newiss 1999; Dedel 2006).

Table 8. Missing Youth and Youth in the General Populations Residing in Group Homes and Foster Homes ${ }^{1}$

\begin{tabular}{|c|c|c|c|c|}
\hline Missing from & $\begin{array}{l}\text { Percent of Missing } \\
\text { Youth (25\% sample) }\end{array}$ & $\begin{array}{l}\text { Percent of } \\
\text { all Youth }\end{array}$ & $\begin{array}{l}\text { Missing Youth as } \\
\text { a Percent of all } \\
\quad \text { Youth }\end{array}$ & $\begin{array}{l}\text { Relative Risk } \\
\text { (versus other } \\
\quad \text { Youth) }\end{array}$ \\
\hline Group/foster home & 57.0 & 0.6 & 38.2 & 201.5 \\
\hline Other & 43.0 & 99.4 & 0.2 & 0.005 \\
\hline Total \% & 100.0 & 100.0 & 0.4 & \\
\hline Unkno & 4 & & & \\
\hline Total & 526 & 123,844 & & \\
\hline \multirow{3}{*}{\multicolumn{5}{|c|}{$\begin{array}{l}X^{2}=18789.096, d f=1, p<0.001 \\
\text { 1. Youth refers to anyone } 19 \text { years old and younger. } \\
\text { Source: Statistics about the number of youth in care in the general population were obtained from } \\
\quad \text { Ontario Association of Children's Aid Services }(2006) \text {. }\end{array}$}} \\
\hline & & & & \\
\hline & & & & \\
\hline \multicolumn{5}{|c|}{$\begin{array}{l}\text { Statistics for the number of youth in Ontario were obtained from Statistics Canada Annual Demo- } \\
\text { graphic Statistics (2005) at: http://www.statcan.gc.ca/pub/91-213-x/91-213-x2005000-eng.pdf }\end{array}$} \\
\hline
\end{tabular}

\section{INTERSECTIONS}

Social exclusion explores the systemic issues that leave particular groups vulnerable to social and economic disadvantage. An intersectional framework complements the concept of social exclusion by exploring how peoples' experiences of disadvantage are augmented and often multiplied if two of more characteristics associated with social exclusion intersect (Knapp 2005; Ontario Human Rights Commission 2001; Crenshaw 1991; Davis 2008). The following section explores intersections of age and gender among all missing persons in the sample and among Aboriginal missing persons. We showed above that youth, women, and Aboriginal people faced a disproportionate risk of going missing. Where two or more of these high risk categories intersect, groups are expected to be overrepresented among people reported missing and experience a disproportionately high risk of being reported missing.

\section{Age and Gender}

Table 9 shows that females in each age group were 1.4 times as likely as their male peers to be reported missing. Compared to the baseline group of males between 0-14 years, males and females 15-19 years old faced a high risk of being reported missing. Females 15-19 years old faced a particularly high risk of being reported missing: they were 6.4 times as likely as males $0-14$ years old — the highest risk of any age-gender group. These findings are consistent with a nation-wide study in Canada which found that among runaways, there were more females compared 
to males (Dalley 2007) and $84 \%$ of female runaways and $81 \%$ of males were between the ages of 14-17 years old (Dalley 2007).

Table 9. Missing Persons and the General Population, by Age and Gender

\begin{tabular}{|c|c|c|c|c|c|}
\hline Age Group & $\begin{array}{c}\text { Percent of } \\
\text { Missing } \\
\text { Persons (25\% } \\
\text { Sample) }\end{array}$ & $\begin{array}{c}\text { Percent of } \\
\text { General } \\
\text { Population }\end{array}$ & $\begin{array}{l}\text { Missing Persons } \\
\text { as a Percent } \\
\text { of the General } \\
\text { Population }\end{array}$ & $\begin{array}{c}\text { Relative Risk } \\
\text { (versus other } \\
\text { Gender) }\end{array}$ & $\begin{array}{c}\text { Relative } \\
\text { Risk (versus } \\
\text { Males, } 0-14 \\
\text { Years) }\end{array}$ \\
\hline \multicolumn{6}{|l|}{ Female } \\
\hline $0-14$ years & 15.3 & 8.7 & 1.0 & 1.4 & 1.4 \\
\hline $15-19$ years & 26.7 & 3.4 & 4.5 & 1.4 & 6.4 \\
\hline $20+$ years & 16.0 & 39.3 & 0.2 & 1.4 & 0.3 \\
\hline$\%$ female & 58.0 & 51.4 & 0.7 & 1.3 & 1.0 \\
\hline \multicolumn{6}{|l|}{ Male } \\
\hline $0-14$ years & 11.2 & 9.1 & 0.7 & 0.7 & - \\
\hline $15-19$ years & 20.0 & 3.5 & 3.3 & 0.7 & 4.7 \\
\hline $20+$ years & 10.8 & 36.0 & 0.2 & 0.7 & 0.3 \\
\hline$\%$ male & 42.0 & 48.6 & 0.5 & 0.8 & 0.7 \\
\hline Total \% & 100.0 & 100.0 & 0.6 & & - \\
\hline Unknown & 1 & & & & \\
\hline Total & 724 & 504,560 & & & \\
\hline
\end{tabular}

Aboriginal Persons, by Age and Gender

Table 10 suggests that Aboriginal females were overrepresented among this sample of missing persons and faced a disproportionate risk of being reported missing compared to Aboriginal males. However, the findings from this study about Aboriginal missing persons should be interpreted with caution as the number of Aboriginal persons in the sample was small, reflecting the small number of Aboriginal persons in this municipality.

Aboriginal females accounted for $69 \%$ of missing Aboriginal persons in this sample whereas only $52 \%$ of Aboriginal people in this city in 2006 were female. Moreover, among Aboriginal persons, females were twice as likely to be reported missing as males. An examination of the three age groups separately shows that, in the two oldest age groups, Aboriginal females faced a higher risk of being reported missing compared to their male peers. Aboriginal females 15-19 years of age were 4.3 times as likely to be reported missing as Aboriginal males in this age group, and Aboriginal females 20+ years were 6.6 times as likely as their male peers. Finally, using Aboriginal males $0-14$ years old as a baseline group, Aboriginal females between 15-19 years old were 4.9 times as likely to be reported missing - by far the highest risk of any age-gender 
Table 10. Aboriginal Missing Persons and All Aboriginal Persons, by Age and Gender

\begin{tabular}{|c|c|c|c|c|c|}
\hline Age Group & $\begin{array}{l}\text { Percent of } \\
\text { Missing } \\
\text { Aboriginal } \\
\text { Persons (25\% } \\
\text { Sample) }\end{array}$ & $\begin{array}{l}\text { Percent } \\
\text { of all } \\
\text { Aboriginal } \\
\text { Persons }\end{array}$ & $\begin{array}{c}\text { Missing Aboriginal } \\
\text { Persons as a } \\
\text { Percent of all } \\
\text { Aboriginal Persons }\end{array}$ & $\begin{array}{l}\text { Relative } \\
\text { Risk (ver- } \\
\text { sus other } \\
\text { Gender) }\end{array}$ & $\begin{array}{c}\text { Relative } \\
\text { Risk (versus } \\
\text { Males, } 0-14 \\
\text { Years) }\end{array}$ \\
\hline \multicolumn{6}{|l|}{ Female } \\
\hline $0-14$ years & 10.3 & 12.8 & 1.5 & 0.6 & 0.6 \\
\hline $15-19$ years & 31.0 & 4.3 & 13.3 & 4.3 & 4.9 \\
\hline $20+$ years & 27.6 & 35.1 & 1.4 & 6.6 & 0.5 \\
\hline $\begin{array}{l}\text { Subtotal } \\
\text { female }\end{array}$ & 69.0 & 52.3 & 2.4 & 2.0 & 0.9 \\
\hline \multicolumn{6}{|l|}{ Male } \\
\hline $0-14$ years & 20.7 & 14.3 & 2.7 & 1.8 & - \\
\hline $15-19$ years & 6.9 & 4.1 & 3.1 & 0.2 & 1.2 \\
\hline $20+$ years & 3.4 & 29.3 & 0.2 & 0.2 & 0.1 \\
\hline $\begin{array}{l}\text { Subtotal } \\
\text { male }\end{array}$ & 31.0 & 47.7 & 1.2 & 0.5 & 0.4 \\
\hline Unknown & 5 & & & & \\
\hline Total \% & 100.0 & 100.0 & 1.8 & & - \\
\hline Total & 29 & 7,615 & & & \\
\hline
\end{tabular}

group of Aboriginal persons. These findings of disproportionate numbers of Aboriginal persons, and of Aboriginal women in particular, in this sample of missing persons are consistent with anecdotal evidence provided by the Native Women's Association of Canada (Native Women's Association of Canada 2009). They are also consistent with the hypothesis that people face very high risks of being reported missing if characteristics associated with social exclusion intersect.

\section{Discussion}

This study shows that excluded groups face a relatively high risk of being reported missing. Youth, women, Aboriginal people, certain visible minorities, homeless people, women escaping domestic violence, youth in care facilities, and people who are unemployed or outside the labour force faced a disproportionately high risk of being reported missing, compared to the general population. Further, if individuals belong to two or more disadvantaged groups, their risk of being reported missing increases as a result. These findings suggest that social exclusion contributes to people's disappearances. Social exclusion also provides insight into why people go missing. 
Going missing emerges often as a response to stressful life events and is common among people who have few resources to rely on to cope with these events. Access to family relationships, employment, and other activities can shield people from stress and harm or, at least, provide people with resources that help them to cope with various misfortunes. People who are excluded, on the other hand, lack access to one or more of these relationships and activities and, as a consequence, may resort to running away or going missing in the face of extreme adversity. Social exclusion can also expose people to circumstances that are risk factors for going missing. For example, excluded youth may end up in foster care and a high number of youth go missing from care facilities. In other words, social exclusion leads directly and indirectly to peoples' disappearances.

This study found that women were overrepresented among persons reported missing whereas, some other studies have found equal numbers of male and female missing persons. This disparity may be due to differing research goals, samples, and/or data sources. Studies whose samples were restricted to adult missing persons or outstanding missing persons, and research based on data obtained from private organizations have found higher numbers of men among missing persons, compared to studies such as this one that are based on police data about youth and adult missing persons. What is clear from many studies is that going missing is a gendered process, because the reasons and risks associated with going missing are different for women and men (James et al. 2008; Public Health Agency of Canada 2006; Gaetz 2004; Kempf-Leonard and Johansson 2007). Among runaway and homeless youth, females are more likely than males to report sexual abuse in the home (Public Health Agency of Canada 2006; Novac 2006).

The gendered nature of going missing is not surprising given that women are more likely to experience social and economic disadvantage compared to men (Carr and Chen 2004). Canadian women face higher poverty rates and earn less than men (Townson 2009). For example, in 2007 , the average earnings of fulltime employed women were only $71 \%$ of the average earnings of men with fulltime employment (Townson 2009). Women are also more likely to be dependent on partners or spouses for subsistence compared to men. For women who are dependent on a partner for subsistence, relationship breakdown and family dissolution often lead to poverty, homelessness, and other problems that are associated with peoples' disappearances (Novac 2006). The fact that $22 \%$ of the missing women in this sample were reported missing from a shelter suggests that homelessness plays a role in women's disappearances. Finally, it is evident from the number of women in this sample 
who were reported missing from a Violence Against Women shelter that women's disappearances are also often related to domestic violence. Therefore, social exclusion contributes to the disappearances of women in unique ways.

Aboriginal people, black people and Latin Americans were overrepresented in this sample of missing persons compared to the general population in this city in 2006. Social exclusion suggests why visible minorities face a disproportionate risk of going missing. In Canada, visible minorities are twice as likely to have incomes below the Low Income Cut-off (LICO) compared to other Canadians (Canadian Centre for Justice Statistics 2001a). In Ontario and in the city from which these data were collected, visible minorities experience higher unemployment rates compared to the general population (Human Resources and Skills Development Canada 2009). Moreover, particular minority groups experience higher levels of social and economic exclusion than other groups. A Canada-wide report on visible minorities found that Latin Americans and black people had higher unemployment rates compared to other visible minorities in 1996 (Canadian Centre for Justice Statistics 2001a). Social and economic exclusion of particular minority groups contributes to a disproportionate risk of going missing for these groups.

Exploring intersections of age, gender, and Aboriginal identity provides more detail about who is at risk of being reported missing. Young women aged 19 years and younger faced a higher risk of being reported missing compared to young men. Women between 15-19 years old faced the highest risk compared to males, $0-14$ years old out of all other genders and age groups. Given that research with homeless youth shows that the majority are male (Public Health Agency of Canada 2006; Hagan and McCarthy 1997), one possible explanation for this finding is that people are more likely to file a missing persons report when a young woman goes missing compared to a man. Aboriginal women between 15-19 years old also faced an extremely high risk of being reported missing. These groups experience age, gender, and Aboriginal identity as multiple barriers to participation in social life (Knapp 2005). As a consequence of high levels of social exclusion, both groups are likely to face risk factors associated with going missing. Youth disappearances are related to family violence and abuse and young women are more likely to report that they left home to escape family violence compared to men (Public Health Agency of Canada 2006). For Aboriginal people, and Aboriginal women in particular, a history of colonization and discrimination have exposed them to low levels of labour market participation, poverty, social isolation from culture and community, and other problems associated with going missing (Amnesty International 2004). 
Racism and gender-based violence have also been implicated in the murders and suspicious disappearances of more than 520 young Aboriginal women in Canada over the past several decades (Native Women's Association of Canada 2009). Of these women, $24 \%$ remain missing and another $67 \%$ were found dead (Native Women's Association of Canada 2009). In Canada, a greater awareness of the link between violence and the disappearances of Aboriginal women surfaced following the Pickton case. Pickton was charged with the murder of 27 women abducted from Vancouver's downtown eastside. ${ }^{8}$ A disproportionate number of these were young Aboriginal women (Native Women's Association of Canada 2009). The above findings have implications for research and policy. Research on missing persons is improved by looking at the intersections of characteristics associated with social exclusion. Policies to prevent the disappearances of young women and young Aboriginal women may be different from those aimed at other groups. The high number of disappearances among Aboriginal women is due in part to the fact that many flee poverty, unemployment, and other problems on reserves and continue to find themselves in vulnerable positions in city centres (Amnesty International 2004). Therefore, strategies to combat the disappearances of Aboriginal women need to focus on funding for counselling, shelters, and other services for Aboriginal women both on and off reserves (Amnesty International 2004).

This research found that homelessness and other changes in living arrangements brought about by family dissolution are also related to individuals going missing. Unfortunately, we were unable to explore directly a major cause of family dissolution that is commonly noted in the background of missing persons - family violence. This is primarily because information about violence and abuse often goes unreported to police officers when someone files a missing persons report. In some cases, information about abuse may be deliberately withheld from police if the person filing the report is also the perpetrator of abuse. However, the relationship between family dissolution and missing persons is evident from the fact that youth in care and shelter users faced a disproportionate risk of going missing. Over one-half the youth in this sample were reported missing from care facilities. Youth often end up in care after experiencing family dissolution, often brought about by family violence or another negative life event. This study shows that youth in care were 200 times as likely to be reported missing as youth not in care, and shelter users were 17 times as likely as nonshelter users to be reported missing. Female shelter users, of whom $88 \%$ were in a Violence Against Women

8. Pickton was convicted of 6 counts of murder. The remaining cases were dropped (CBC News Canada 2010). 
(VAW) shelter, were five times as likely as male shelter users to be reported missing. In Canada, $75 \%$ of women who rely on VAW shelters are escaping domestic violence (Sauvé and Burns 2009). Therefore, youth in care and shelter users faced a disproportionate risk of going missing indicating that family dissolution that is often brought about by violence or some other negative life event is linked to going missing.

Another important finding is that labour force status is related to peoples' disappearances. First, people who were unemployed were overrepresented among this sample of missing persons compared to the general population and faced a higher risk of being reported missing compared to employed persons. One study in the U.K. found that financial crises were a major reason for adult disappearances (Biehal et al. 2003). Financial crises may be initiated or exacerbated by persistent unemployment. The relationship between unemployment and going missing is also indirect, since persistent unemployment often leads to poverty and homelessness which are also risk factors for going missing. Second, people who were not in the labour force faced a disproportionate risk of being reported missing compared to employed persons. The well-being of these people is often tied to primary income earners in the household. If these people experience family dissolution the effects are particularly devastating, often leading to poverty, homelessness, and other risk factors associated with going missing. The labour market and the family are two key institutions which provide income, social integration, and support. Exclusion from either institution is associated with a disproportionate risk of going missing. The high risk of being reported missing for those not in the labour force reflects the extreme deprivation associated with being shut out of both the labour market and the family.

There are certain limitations that stem from the data sources used in this research. First, there are several dimensions of social exclusion that cannot be tested in this research because information was not available from the missing persons sample or the general population. For example, mental illness is also associated with exclusion (Percy-Smith 2000), and this group goes missing in high numbers (Patterson 2005; Biehal et al. 2003; Tarling and Burrows 2004). However, information about the prevalence of mental illness in the city where these data were collected was not available. Substance abuse and prostitution, also often associated with peoples' disappearances, generally go undisclosed to the police. Second, police data likely underestimate the number of people reported missing, particular socially excluded people who may have no one in their social network who notices that they are missing or is willing to interact with the police in order to report them as missing. Third, the data for this research deals with incidents not individuals and it is 
possible that people are represented more than once in these data. These limitations highlight the need for alternative data sources to examine the phenomenon of going missing. In particular research needs to explore the risk of disappearances among the most disadvantaged and marginalized groups as these people and groups may be unlikely to be reported missing. Anecdotal evidence suggests that Aboriginal women go missing in high numbers and yet many of these disappearances are not reported to the police (Native Women's Association of Canada 2009). Research should also explore the linkages between going missing and mental illness, poverty, and other dimensions of social exclusion not captured in police reports. These improvements would allow a more thorough exploration of the relationship between going missing and social exclusion.

\section{CONCLUSION}

This article makes several contributions to the literature on missing persons. It systematically examines many of the correlates of being reported missing for both youth and adults in one Canadian city. Second, it incorporates a comparison group from the general population to provide statistical analyses of risk factors associated with people who are reported missing. One of the main benefits of this analysis is to show that many marginalized groups and individuals such as youth, women, Aboriginal people, visible minorities, the unemployed, and homeless people face a high risk of being reported missing. The high risk faced by these disadvantaged groups indicates that structural issues play a role in peoples' disappearances. In particular social exclusion is related to peoples' disappearances.

Social exclusion explains how structural disadvantage leaves people unable to cope with adverse life events and, as a result, some people perceive running away or going missing to be the only option. It is also important to note that some people who go missing are at risk of experiencing problems that expose them to further exclusion and deintegration from mainstream society. A U.K. study with runaway youth found that these youth faced a high risk of encountering problems later in life, including drug abuse, homelessness, and crime (Social Exclusion Unit 2002). In other words, going missing may serve as an important indicator of people at risk of experiencing social exclusion; providing programs and services for these people and groups is one way to reduce peoples' experiences of social and economic disadvantage.

From a policy perspective the link between going missing and social exclusion means that policies of prevention and intervention should 
focus on poverty reduction, overcoming discrimination, ending violence and abuse in the home, and other systemic issues that underlie peoples' disappearances. More specifically, policies of prevention and intervention should focus on people and groups who face a high risk of going missing and on the structural conditions underpinning their disappearances. Youth are often forced to flee in response to family violence and conflict, problems they experience in care, homelessness, and other serious problems. Some strategies that show promise in addressing youth disappearances include child abuse prevention, suicide prevention, and offering counselling and mentorship to youth and families in crisis (James et al. 2008; Social Exclusion Unit 2002). In other words, programs and policies developed to target other important social problems will also reduce the likelihood of going missing.

As youth face a high risk of being reported missing, policies need to be refined and expanded to target the needs of young people at risk. A British report explains that counselling services that provide youth with alternatives to running away are vital in reducing problems in the home and, in turn, lower the risk of youth going missing (Social Exclusion Unit 2002). Young runaways who were interviewed reported that having someone to talk to about their problems would have helped prevent them from running away (Social Exclusion Unit 2002). Similarly, parents and family members of runaway youth reported that they lacked the tools and skills to talk to their children about problems (Social Exclusion Unit 2002). In other words, early intervention that provides youth and families with the skills to talk about problems and offers youth alternatives to running away is essential in reducing the high number of youth disappearances. Another strategy of intervention focuses on providing education and information to social service agencies, health care workers, teachers, and the community about the complex reasons and risks associated with running away (Social Exclusion Unit 2002). Fostering a sense of understanding in the community that running away is motivated often by serious underlying problems and exposes youth to real dangers will ensure that youth at risk of running away are seen as needing intervention rather than just rebellious teens.

Although relatively little is known about intervention and prevention in adult disappearances the high risk of being reported missing for disadvantaged and marginalized adults means that effective policies should focus on poverty prevention, employment opportunities, job training and education, and ending homelessness, domestic violence, and other social problems that affect excluded groups. Crisis intervention and improved health care for homeless people helps reduce the stigma and shame associated with homelessness (James et al. 2008). This in turn may lower 
the risk of homeless people severing ties with families who in turn report them as missing (James et al. 2008). However, strategies designed specifically to combat adult disappearances are also needed. Future research should focus more closely on adult disappearances to identify risk factors and correlates that can be translated into effective policies of prevention and intervention.

Applying the concept of social exclusion to the phenomenon of going missing offers a window into the systemic factors that are associated with peoples' disappearances and refutes the common misconception that going missing is a simple choice. Rather, even if it appears that people made a choice to go missing, they are often fleeing violence, conflict, abuse, and other circumstances over which they have limited control. In order to prevent disappearances and limit further exclusion, policies must target at-risk groups and provide people with alternatives to going missing such as counselling, crisis intervention, financial and social support.

\section{REFERENCES}

Amnesty International. 2004. Canada: Stolen sisters: A human rights response to discrimination and violence against Indigenous women in Canada. Retrieved March 2, 2008 http://www.amnesty.ca/campaigns/resources/ amr2000304.pdf.

Association of Chief Police Officers (ACPO) and National Centre for Policing Excellence (CENTREX). 2005. Guidance on the Management, Recording and investigation of Missing Persons. Bramshill: National Centre for Policing Excellence.

Biehal, Nina, Fiona Mitchell, and Jim Wade. 2003. Lost From View: Missing Persons in the UK. Bristol: The Policy Press.

Burchardt, Tania, Julian Le Grand, and David Piachaud. 1999. Social exclusion in Britain 1991-1995. Social Policy and Administration 33(3):227-244.

Burnstein, Meyer. 2005. Combating the social exclusion of at-risk groups. Retrieved March 12, 2008 http://www.policyresearch.gc.ca/doclib/DP PEX_Burstein_200511_e.pdf.

Byrne, David. 2005. Social Exclusion: Issues in Society. Second Edition. Philadelphia: Open University Press.

Canadian Centre for Justice Statistics. 2001. Visible minorities in Canada. Retrieved November 12, 2009 http://dsp-psd.pwgsc.gc.ca/Collection/Statca n/85F0033M/85F0033MIE2001009.pdf.

Canadian Centre for Justice Statitistics. 2001. Aboriginal peoples in Canada. Retrieved February 3, 2011. http://dsp-psd.pwgsc.gc.ca/Collection/Statcan/ 85F0033M/85F0033MIE2001001.pdf. 
Carr, Marilyn and Martha Chen. 2004. Globalization, social exclusion and gender. International Labor Review 143(1-2):129-160.

CBC News Canada. (2010, August 9). Pickton Trial Timeline. Retrieved June 19, 2012 http://www.cbc.ca/news/canada/story/2010/07/30/f-picktontrial-timeline.html.

Charette, Michael and Ronald Meng. 1994. The determinants of welfare participation of female heads of household in Canada. Canadian Journal of Economics 27(2):290-306.

Cohen Irwin M., Amanda V. McCormick, and Darryl Plecas. 2008. A review of the nature and extent of uncleared missing persons cases in British Columbia. Retrieved September 4, 2010 http://www.ufv.ca/Assets/CCJR/ Reports+and+Publications/Missing_Persons.pdf.

Crenshaw, Kimberle W. 1991. Mapping the margins: Intersectionality, identity politics, and violence against women of color. Stanford Law Review 43(6):1241-1299.

Crespi, Tony D. and Ronald M. Sabatelli. 1993. Adolescent runaways and family strife: A conflict induced resolution framework. Adolescence 28:867878.

Dalley, Marlene. 2007. Missing children reference report national missing children services. Retrieved October 4, 2009 http://www.rcmp-grc.gc.ca/ pubs/omc-ned/an-ra/annrep-rappann-06-eng.htm\#3.

Davis, Kathy. 2008. Intersectionality as buzzword: A sociology of science perspective on what makes a feminist theory successful. Feminist Theory 9(1):67-85.

Dedel, Kelly. 2006. Juvenile runaways. Retrieved August 6, 2009 http://www. cops.usdoj.gov/mime/open.pdf?Item=1694.

Fergusson, Ross. 2004. Discourses of social exclusion: Reconceptualising participation amongst young people. Journal of Social Policy 32(3):289320.

Gaetz, Stephen. 2004. Safe streets for whom? Homeless youth, social exclusion, and criminal victimization. Canadian Journal of Criminology and Criminal Justice 46(4):423-455.

Gaetz, Stephen and Bill O'Grady. 2002. Making money: Exploring the economy of homeless workers. Work, Employment, and Society 16:433-456.

Gondolf, Edward W. 1988. The effect of batterer counselling on shelter outcome. Journal of Interpersonal Violence 3(3):275-289.

Hagan, John, and Bill McCarthy. 1997. Mean Streets: Youth Crime and Homelessness. New York: Cambridge University Press.

Hall, Neal (2012, January 27). RCMP apologize for not doing enough to solve missing women case sooner. Vancouver Sun, Online. Retrieved February 4, 2012 http://www.missingpeople.net/rcmp_apologize_for_not_doing. htm. 
Hanvey, Louise. 2003. Social inclusion research in Canada: Children and youth. Retrieved July 1, 2011 http://www.ccsd.ca/events/inclusion/papers/hanvey.pdf.

Human Resources and Skills Development Canada. 2009. Fact sheet on members of designated groups. Retrieved November 24, 2009 http://www. hrsdc.gc.ca/eng/labour/equality/employment equity/tools/eedr/2006/ index.shtml.

James, Marianne, Jessica Anderson, and Judy Putt. 2008. Missing Persons in Australia. Canberra: Australian Institute of Criminology.

Kantor-Kaufman Glenda and Jana Jasinski. 1998. Dynamics and risk factors in partner violence. Pp. 1-44 in Jana L. Jasinski and Linda M. Williams, ed., Partner Violence: A Comprehensive Review of 20 Years of Research. Thousand Oaks, CA: Sage.

Kempf-Leonard, Kimberly and Pernilla Johansson. 2007. Gender and runaways: Risk factors, delinquency, and juvenile justice experiences. Youth Violence and Juvenile Justice 5:308-327.

Knapp, Gudrun-Axeli. 2005. Race, class, gender: Reclaiming baggage in fast travelling theories. European Journal of Women's Studies 12(3):249-265.

Lee, Barrett and Christopher Schreck. 2005. Danger on the Streets: Marginality and victimization among homeless people. American Behavioral Scientist 48(8):1055-1081.

Lee, Barrett and Townsand Price-Spratlen. 2004. The geography of homelessness in American communities: Concentration or dispersion? City \& Community 3:3-27.

Native Women's Association of Canada (NWAC). 2009. Voices of our sisters in spirit: A report to families and communities, $2^{\text {nd }}$ Edition. Retrieved August 1, 2009 http://www.nwac.ca/sites/default/files/download/admin/ NWAC VoicesofOurSistersInSpiritII_March2009FINAL.pdf.

Newiss, Geoff. 1999. Missing presumed...? The police response to missing persons. Policing and Reducing Crime Unit: Police Research Series: London.

2004. Estimating the risk faced by missing persons: A study of homicide victims as an example of an outcome-based approach. International Journal of Police Science and Management 6(1):27-36.

2005. A Study of the characteristics of outstanding missing persons: Implications for the development of police risk assessment. Police and Society 15(2):212-225.

Noël, Alain and Florence Larocque. 2009. Aboriginal peoples and poverty in Canada: Can provincial governments make a difference? Retrieved September 152010 http://www.cccg.umontreal.ca/RC19/PDF/Noel-A Rc192009.pdf.

Novac, Sylvia. 2006. Family Violence and Homelessness: A Review of the Literature. Ottawa: Minister of Health. 
Ontario Association of Children's Aid Services. 2006. Youth leaving care: An OACAS study of youth and CAS staff. Retrieved November 18, 2009 (http://www.oacas.org/about/programs/youthcan/07conference/youthleavingcare07oct25.pdf).

Ontario Human Rights commission. 2001. An intersectional approach to discrimination. Ottawa: Policy and Education branch. Retrieved November 1, 2009 (http://www.ohrc.on.ca/en/resources/discussion_consultation/ DissIntersectionalityFtnts/pdf).

Patterson, Marla-Jean. 2005. Who is missing? A study of missing persons in B.C. (MA thesis, Simon Frasier University).

Payne, Malcolm. 1995. Understanding going missing: Issues for social work and social services. British Journal of Social Work 25:333-348.

Peace, Robin. 2001. Social Exclusion a concept in need of definition? Social Policy Journal of New Zealand 6(1):17-35.

Percy-Smith, Janie. 2000. Introduction: the contours of social exclusion. Pp. 1-22 in J. Percy-Smith, eds., Policy Responses to Social Exclusion: Towards Inclusion? Philadelphia: Open University Press.

Phipps, Shelley and Peter Burton. 1995. Sharing within families: Implications for the measurement of poverty among individuals in Canada. Canadian Journal of Economics 28:177-204.

Public Health Agency of Canada. 2008. Breaking the links between poverty and violence against women: A resource guide. Retrieved September 6, 2011 (http://www.phac-aspc.gc.ca/ncfv-cnivf/pdfs/fem-brklnks-eng.pdf). 2006. Enhanced surveillance of street youth in Canada. Retrieved February 21, 2008 (http://www.phac-aspc.gc.ca/std-mts/reports_06/pdf/ street_youth_e.pdf).

Richter, Magdalena and Jean Chaw-Kant. 2008. A case study: Retrospective analysis of homeless women in a Canadian city. Women's Health and Urban Studies 7(1):7-9.

Room, Graham. 1995. Poverty and social exclusion: The new European agenda for policy and research. Pp. 1-10 in G. Room, ed., Beyond the Threshold: The Measurement and Analysis of Social Exclusion. Bristol: The Policy Press.

Saskatchewan Association of Chiefs of Police (SACP). 2007. Retrieved February 18, 2007 (www.sacp.ca/missing/index.php).

Sauvé, Julie and Mike Burns. 2009. Residents of Canada's Shelters for Abused Women, 2008. Catalogue no. 85-002-X, vol. 29, no. 2. Ottawa: Statistics Canada.

Sen, Amartya. 2000. Social exclusion: Concept, application and scrutiny, social Development. Paper No. 1. Office of Environment and Social Development, Asia Development Bank. Retrieved September 4, 2005 (http:// www.adb.org/Documents/Books/Social Exclusion/Social exclusion. pdf). 
Silver, Hilary. 1994. Social exclusion and social solidarity: Three paradigms. International Labour Review 133(5-6):531-78.

Social Exclusion Unit. 2000. National strategy for neighbourhood renewal: policy action team 17 - Linking it up locally. Retrieved 4 September 2005 http://www.communities.gov.uk/documents/localgovernment/ pdf/135457.pdf.

2002. Young Runaways: Report be the Social Exclusion Unit. Retrieved October 24, 2006 http://www.bris.ac.uk/poverty/downloads/keyofficialdocuments/Young\%20Runaways.pdf.

Social Planning and Research Council. 2007. On any given night: Measuring homelessness in Hamilton. Retrieved July 7, 2009 http://www. hamilton.ca/NR/rdonlyres/A85A4701-C327-459D-A66E-19D81CFA6A99/0/ OnAnyGivenNight 2007.pdf.

Statistics Canada. 2003. Aboriginal Peoples Survey 2001 - Initial Findings: Well-being of the Non-reserve Aboriginal Population. Statistics Canada, Catalogue no. 89-589-XIE. Retrieved October 12, 2011 http://www.statcan.gc.ca/pub/89-589-x/89-589-x2003001-eng.pdf.

Tarling, Roger and John Burrows. 2004. The nature and outcome of going missing: The challenge of developing effective risk assessment procedures. International Journal of Police Science and Management 6(1):16-26.

Townson, Monica. 2009. Women's Poverty and the Recession. Ottawa, ON: Canadian Centre for Policy Alternatives. Retrieved September 14, 2010 http://www.policyalternatives.ca/sites/default/files/uploads/publications/ National Office Pubs/2009/Womens Poverty in the Recession.pdf.

Laura Kiepal is a $\mathrm{PhD}$ student at the University of Waterloo in the department of Sociology. She received her Master's degree in sociology and undergraduate degree in Criminal Justice and Public Policy from the University of Guelph. Her research interests lie in the area of missing persons, marginalized groups, and social exclusion. Currently she is completing her dissertation which examines risk and causal factors in going missing and factors linked to the duration of peoples' disappearances.

Peter J. Carrington is Professor of Sociology and Legal Studies at the University of Waterloo and editor of Canadian Journal of Criminology and Criminal Justice. He is currently researching co-offending and criminal networks. His work has recently been published in Criminology, Canadian Journal of Criminology and Criminal Justice, and Criminal Justice Policy Review. He is co-editor of The SAGE Handbook of Social Network Analysis (2011) and Models and Methods in Social Network Analysis (2005).

Myrna Dawson is a Canada Research Chair in Public Policy in Criminal Justice and Associate Professor, Department of Sociology and Anthropology, University of Guelph, Ontario. Her research focuses on social and legal responses to violent victimization with particular emphasis on intimate partner violence and homicide. She is author of numerous scholarly articles and research reports and co-author of the Violence Against Women in Canada: Research and Policy Perspectives (2011, Oxford University Press). 